\title{
Diverse developmental strategies of $X$ chromosome dosage compensation in eutherian mammals
}

\author{
ALEXANDER I. SHEVCHENKO*,1,2,3,4, ELENA V. DEMENTYEVA ${ }^{1,2,3}$, IRINA S. ZAKHAROVA $^{1,2,3}$ and \\ SUREN M. ZAKIAN $1,2,3,4$

\begin{abstract}
${ }^{1}$ Federal Research Centre "Institute of Cytology and Genetics of the Siberian Branch of the Russian Academy of of Sciences, ${ }^{3}$ E.N. Meshalkin National Medical Research Centre, Ministry of Healthcare of the Russian Federation and ${ }^{4}$ Novosibirsk State University, Novosibirsk, Russia
\end{abstract} \\ Sciences", 'Institute of Chemical Biology and Fundamental Medicine of the Siberian Branch of the Russian Academy
}

\begin{abstract}
In eutherian mammals, dosage compensation arose to balance $X$-linked gene expression between sexes and relatively to autosomal gene expression in the evolution of sex chromosomes. Dosage compensation occurs in early mammalian development and comprises $\mathrm{X}$ chromosome upregulation and inactivation that are tightly coordinated epigenetic processes. Despite a uniform principle of dosage compensation, mechanisms of $X$ chromosome inactivation and upregulation demonstrate a significant variability depending on sex, developmental stage, cell type, individual, and mammalian species. The review focuses on relationships between $X$ chromosome inactivation and upregulation in mammalian early development.
\end{abstract}

KEY WORDS: dosage compensation, mammal, $X$ chromosome upregulation, $X$ chromosome inactivation, Xist

\section{Mammalian dosage compensation system}

Early embryonic development of eutherian mammals is closely linked with dosage compensation of $X$ chromosome genes. Mammalian $X$ and $Y$ chromosomes differ significantly in gene content and play a key role in sex determination. $Y$ chromosome determines male development. Itcontains less than 100 genes and is a depleted variant of ancestral Xchromosome. Conversely, X chromosome increased gene number during evolution by autosomal translocations and comprises more than 1100 genes (Deng et al., 2014). In most mammals, males have $X$ and $Y$ chromosomes whereas females carry two $X$ chromosomes. Thus, male $X$ chromosome does not seem to be compensated for gene dosage relatively to two female $\mathrm{X}$ chromosomes and two copies of autosomes. However, two processes occur in mammals to correct the imbalance. X chromosome inactivation $(\mathrm{XCl})$ results in transcriptional silencing of one of the two $X$ chromosomes in females, balancing dose of $X$-linked genes between sexes (Lyon 1961). X chromosome upregulation (XCU) doubles $\mathrm{X}$-linked genes expression on the active $\mathrm{X}$ chromosome in both males and females, equalizing $X$-linked genes expression and biallelic expression of autosomal genes (Dementyeva et al., 2009; Deng et al., 2014; Nguyen and Disteche 2006). Therefore, in mammals, males have one active upregulated $X$ chromosome (Xa) while females carry one active upregulated $X$ chromosome
(Xa) and one inactive $X$ chromosome (Xi) (Fig. 1).

$\mathrm{XCl}$ is a well coordinated chromosome-wide epigenetic process controlled by a long non-coding RNA of the Xist gene in eutherians. Xist RNA is a nuclear transcript being expressed exclusively on the inactivated $\mathrm{X}$ chromosome. After $\mathrm{XCl}$ initiation, Xist RNA spreads along the $X$ chromosome due to its capacity to bind nuclear proteins, is maintained in Xi chromatin, represses gene transcription, and forms facultative heterochromatin and $\mathrm{Xi}$ chromosome territory (Moindrot and Brockdorff 2016; Pinter 2016; Przanowski et al., 2018). However, in somatic tissues, gene silencing and $\mathrm{Xi}$ chromatin can be maintained in the absence of Xist RNA.

XCU has been studied to a lesser extent but seems to be a highly concerted process. XCU is rapidly established in a chromosomewide manner in male and female early development and is quickly

\footnotetext{
Abbreviations used in this paper: $\mathrm{ESC}$, embryonic stem cell; iPSC, induced pluripotent stem cell; iXCI, imprinted X chromosome inactivation affects predominately paternal X chromosome; PSC, pluripotent stem cell; rXCI, random X chromosome inactivation represses paternal and maternal $\mathrm{X}$ chromosomes with equal probability; TS cell, trophoblast stem cell; Xa, active X chromosome; XCI, X chromosome inactivation; XCU, X chromosome upregulation; Xe, X chromosome with eroded $\mathrm{XCI}$; XEN, extraembryonic endoderm stem cell; $\mathrm{Xi}$, inactive $\mathrm{X}$-chromosome; $\mathrm{Xm}, \mathrm{X}$ chromosome of maternal origin; $\mathrm{Xp}, \mathrm{X}$ chromosome of paternal origin.
}

*Address correspondence to: Alexander I. Shevchenko. Federal Research Centre "Institute of Cytology and Genetics of the Siberian Branch of the Russian Academy of Sciences", Prospekt Lavrentyeva, 10, Novosibirsk 630090, Russia. Tel: +7(383)3634937. E-mail: epigene@ bionet.nsc.ru - (iD) https://orcid.org/0000-0001-6535-1627. 


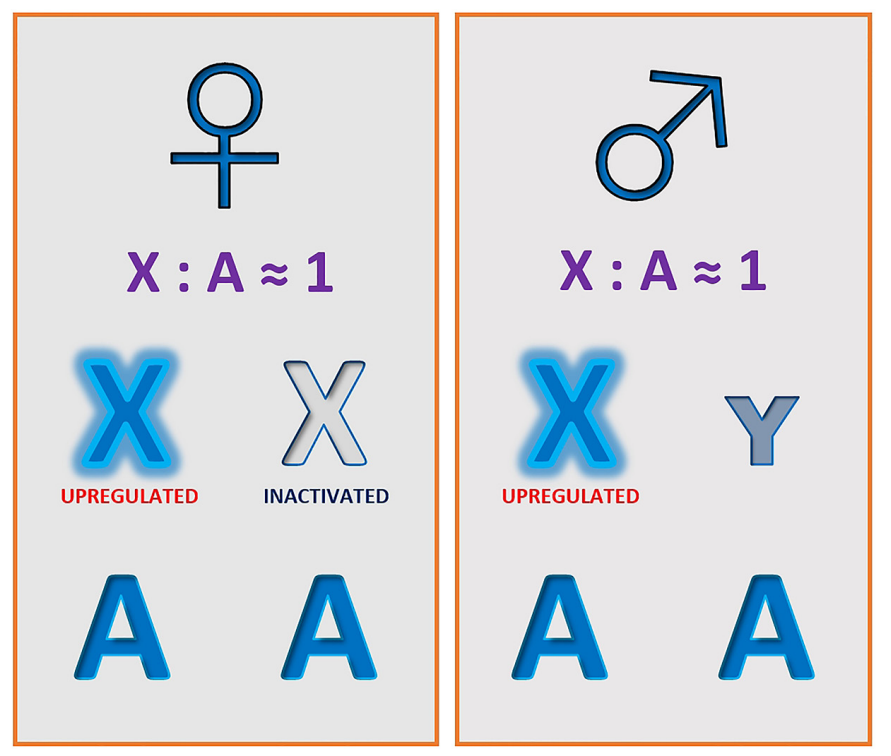

Fig. 1. Dosage compensation system in eutherian mammals. In females $(X X)$, one $X$ chromosome is upregulated and the other is inactivated. In males $(X Y)$, the only $X$ chromosome is upregulated. This provides equal expression of $X$-linked genes between sexes and equal expression between $X$-linked and autosomal genes. $X, X$ chromosome; $Y, Y$ chromosome; $A$, autosomal set. The upregulated $X$ chromosome is highlighted in blue; the inactive $X$ chromosome is shown in white and the $Y$ chromosome is indicated in grey.

switched off in gametogenesis despite the fact that different genes may use various mechanisms to increase transcription level (Borensztein et al., 2017b; Nguyen and Disteche 2006; Sangrithi et al., 2017).

Disruptions in dosage compensation revealed, mainly, due to $\mathrm{XCl}$ studies lead to dramatic effect on organism. Defects in $\mathrm{XCI}$ during embryogenesis result in fetus death (Borensztein et al., 2017b; Lee 2000; Marahrens et al., 1997). Imbalance of gene expression caused by sex chromosome aneuploidies leads to a number of genetic syndromes (Nagaoka et al., 2012). Xi reactivation in female cells may cause oncologic (Dunford et al., 2017; Spatz et al., 2004), autoimmune (Forsdyke 2009), and age-related diseases (Ostan et al., 2016).

Balance of dosage compensation mechanisms varies between developmental stages and mammalian species. Moreover, X-linked genes are differently involved in dosage compensation. In the review, relationships between $\mathrm{XCU}$ and $\mathrm{XCI}$ and their dependence on sex, developmental stage, cell type, tissue, and mammalian species will be discussed.

\section{$\mathrm{X}$ chromosome upregulation}

Dosage compensation between X-chromosome and autosomal genes was first postulated by Susumu Ohno in the 1960s (Ohno 1967). However, XCU at chromosomal level was confirmed only in the last decade and studied in detail using transcriptomic data obtained from microarray (Lin et al., 2007; Nguyen and Disteche 2006), RNA sequencing (Deng et al., 2011, 2013; Julien et al., 2012; Lin et al., 2011; Xiong et al., 2010; Yildirim et al., 2011), and ribosome profiling assays (Faucillion and Larsson, 2015). XCU was revealed by calculating $X$ :A ratio obtained by dividing median gene expression levels of $\mathrm{X}$-linked genes by that of autosomal genes. $X: A$ close to 1 means equal expression of $X$-linked and autosomal genes, implying that XCU takes place. XCU was found in mouse, rat, and human somatic tissues, early embryos, and embryonic stem cells. Nonetheless, in several studies, $\mathrm{X}$ :A ratio was found close to 0.5, rejecting XCU (Julien et al., 2012; Xiong et al., 2010). $\mathrm{Re}$-examination of the inconsistent result demonstrated that $\mathrm{Xa}$ comprised a large portion of transcriptionally silenced genes decreased median level of X-linked gene expression (Deng et al., 2011; Kharchenko et al., 2011). Exclusion of numerous tissue-specific genes with extremely low and high expression levels as the genes were not relevant for the evaluation of dosage compensation restored X:A ratio up to 1. However, XCU was not confirmed at the translation level using proteome analysis (Chen and Zhang 2015).

As XCl, XCU initiates in early embryogenesis. In mice, according to single cell RNA sequencing data, XCU was observed from the 4-cell stage (Borensztein et al., 2017b). Doubling transcription on mouse Xa was confirmed for all ontogenesis stages - from early embryonic development to adult somatic tissues (Deng et al., 2011, 2013; Lin et al., 2007). Single cell RNA sequencing of human embryos first detected XCU at the blastocyst stage (Moreira de Mello et al., 2017). A loss of XCU as well as XCl occurs during global genome reprogramming in primordial germ cells of both sexes in mice and humans (Sangrithi et al., 2017; Moreira de Mello et al., 2017). In early female germ cells, $\mathrm{Xi}$ is reactivated while $\mathrm{Xa}$ remains upregulated. As a result, $\mathrm{X}$-linked genes are overexpressed relatively to autosomal genes and $\mathrm{X}$ :A ratio exceeds 1. Later, XCU appears to be switched off because $X$ :A ratio returns to 1 in females but becomes below 1 in males. The skewed X-linked gene dosage found in both sexes may promote sexual dimorphism in germ line development, which is necessary for correct gametogenesis and may account for infertility of individuals with sex chromosome aneuploidies.

$\mathrm{XCU}$ is based on increasing transcription level and changes in mRNA stability. Transcription can be elevated by RNA Polll phosphorylation and histone modifications such as MOF-mediated H4K16 acetylation and high level of trimethylated H3K4 that promote open chromatin structure (Deng et al., 2013; Yildirim et al., 2011). In addition, transcript half-life was shown to be longer for X-linked genes (Deng et al., 2013; Faucillion and Larsson 2015; Yildirim et al., 2011) and to be shorter for autosomal genes (Yin et al., 2009). However, mechanisms regulating mRNA stability are still unknown. X-linked genes may use one or several mechanisms to be upregulated. For example, in mouse embryonic stem cells (ESCs), transcription level of 69 genes depended on MOF histone-methyltransferase but only $60 \%$ of the genes demonstrated increased mRNA stability (Deng et al., 2013). Thus, transcription upregulation and increasing mRNA stability may be independent XCU mechanisms.

$\mathrm{XCU}$ affects genes of both conservative and added regions of $X$ chromosome but to various extents (Deng et al., 2013). In all tissues, ubiquitously expressed housekeeping $\mathrm{X}$-linked genes are upregulated. Dosage of X-linked genes encoding subunits forming protein complexes together with autosomal products is expected to be regulated more strictly (Pessia et al., 2012). In addition, downregulation of autosomal genes may also occur to equalize their expression level relatively to that of $X$-linked genes (Julien et al., 2012). Tissue-specific X-linked genes responsible for gametogenesis and being expressed predominantly in testis 
and ovaries are repressed and, therefore, do not undergo XCU in somatic tissues (Deng et al., 2014; Pessia et al., 2012). XCU also does not affect $\mathrm{X}$-linked genes that escape $\mathrm{XCI}$ and are expressed biallelically (Dementyeva et al., 2009; Deng et al., 2014). Expression of some X-linked genes remains unbalanced. Their expression level is thought not to be important for cell or the unbalanced expression may have functional significance, e.g. it contributes to sex-specific features.

\section{Imprinted $X$ chromosome inactivation in rodents}

Imprinted $\mathrm{X}$ chromosome inactivation (iXCl) takes place in rodent preimplantation embryo and extraembryonic tissues. iXCI was described in mice (Takagi and Sasaki 1975), rats (Wake et al., 1976), and common voles (Dementyeva et al., 2010; Shevchenko et al., 2011). During iXCI paternally inherited X chromosome (Xp) is inactivated. In mice, imprinting protecting maternally inherited $\mathrm{X}$ chromosome $(\mathrm{Xm})$ from $\mathrm{XCl}$ is supposed to be established in oogenesis. Due to the maternal imprinting mouse embryos carrying two $\mathrm{Xm}(\mathrm{XmXmXp}$ or $\mathrm{XmXmY})$ cannot inactivate extra $\mathrm{Xm}$ and die because of defects in extraembryonic tissues (Shao and Takagi 1990; Tada et al., 2000). Antisense RNA of the Tsix gene which is not expressed on Xp was proposed to repress Xist on $\mathrm{Xm}$ protecting it from inactivation during $\mathrm{iXCl}$ in mice (Lee 2000). However, Xist was shown to be inhibited on Xm by Tsix RNA in differentiated trophectoderm cells rather than in preimplantation mouse embryo (Maclary et al., 2014). A recent study links initial Xm imprint with a high level of trimethylated H3K27 (H3K27me3) in its Xist locus. The modification is established during oocyte growth and is retained in mouse preimplantation development (Inoue et al., 2017). Loss of H3K27me3 leads to initiation of Xist expression on $\mathrm{Xm}$ and subsequent $\mathrm{Xm}$ inactivation in preimplantation embryos. Correct $\mathrm{iXCl}$ initiation in mice is also controlled by protein of an X-linked gene, Rnf12 (Shin et al., 2010). The protein is a RLIM ubiquitin ligase regulating activity of various transcription factors and co-factors. Rnf12 knockout in oocytes where a huge amount of RLIM is normally present interferes with $\mathrm{XXCl}$ in female embryos due to inhibition of Xist RNA cloud formation on Xp, which causes embryo death. Thus, different mechanisms may be involved in $\mathrm{XCI}$ imprinting during early mouse development.

After the first division of mouse zygote, at the 2-cell stage, Xp and $\mathrm{Xm}$ genes are transcriptionally active with no pre-inactivation signs on Xp (Borensztein et al., 2017b; Deng et al., 2014; Okamoto and Heard 2006) (Fig. 2). iXCI begins at the 4-cell stage when Xp is coated with Xist RNA. Xp is gradually inactivated during preimplantation development as facultative heterochromatin is formed. Early-silenced genes are located in $\mathrm{X}$ chromosome regions that are first to bind Xist RNA. Intermediate and late silencing occurs in the regions that are located next to and outside first Xist RNA 'entry' sites, respectively. The inactivation process is completed by the blastocyst stage when about $85 \%$ of Xp genes undergo silencing (Borensztein et al., 2017b).

In mouse preimplantation development, expression of $X$-linked genes can remain unbalanced (Borensztein et al., 2017b). X:Aratio significantly exceeds 1 in single blastomeres beginning from the 4-cell stage, implying abundance of $X$ chromosome transcripts. This may be accounted for the fact that active Xm was already upregulated whereas Xp was not completely inactivated. Overexpression of X-linked genes relatively to autosomal genes is observed up to the blastocyst stage when $\mathrm{X}$ :A ratio approaches to 1 .

In the absence of $X$ ist expression $\mathrm{iXCl}$ is not triggered and gene transcription is not repressed (Borensztein et al., 2017b; Namekawa et al., 2010). Absence of Xist expression during mouse iXCI causes global changes in transcriptome of preimplantation embryo cells (Borensztein etal., 2017b). On the one hand, abnormal overexpression of several pluripotency genes that maintain blastomeres in a poorly differentiated state is observed. On the other hand, aberrant expression of genes involved in differentiation and extraembryonic tissues formation is revealed. The transcriptome alterations result in development abnormalities detected from the blastocyst stage and finally cause embryo death.

Trophoblast stem (TS) and extraembryonic endoderm stem (XEN) cells giving rise to extraembryonic tissues (placenta and yolk sac) are derived from preimplantation rodent (mouse and vole) embryos and are actively used to study iXCI (Calabrese et al., 2012; Merzouk et al., 2014; Prudhomme et al., 2015; Shevchenko et al., 2009, 2018; Vaskova et al., 2014). It was shown that 13-15\% of $\mathrm{X}$-linked genes are not inactivated on $\mathrm{Xi}$ and expressed from both $\mathrm{X}$ chromosomes in mouse TS and XEN cells (Calabrese et al., 2012; Merzouk et al., 2014). However, the patterns of genes escaping $\mathrm{XCl}$ in mouse TS and XEN cells have some specific traits. Similar data on incomplete $\mathrm{iXCl}$ and peculiarities of genes escaping $\mathrm{XCl}$ were obtained when studied X-linked gene expression in vole placentas and XEN cells (Dementyeva et al., 2010).

During differentiation of mouse TS cells into trophoblast derivatives transcriptional silencing of $X p$ becomes more relaxed. This is confirmed by increased reactivation frequency of endogenous loci and transgenic constructions on Xp (Corbel et al., 2013; Hemberger et al., 2001). Xp reactivation can be increased by inhibition of methyltransferases of PRC2 complex that seems to maintain iXCI in differentiated cells of trophectoderm via H3K27 trimethylation (Kalantry et al., 2006; Wang et al., 2001). It was found that Xp in mouse TS cells could lose an inactive state and become completely reactivated. However, no obvious changes in cell phenotype like differentiation, malignization or reprogramming were observed (Prudhomme et al., 2015). TS cell clones carrying two active $X$ chromosomes are capable to secondary non-random $\mathrm{XCl}$. The same $X$ chromosome is chosen to be inactivated in the cells of a certain clone. In most cases, Xp is repeatedly inactivated. However, Xm sometimes is inactivated de novo. In visceral endoderm and yolk sac representing differentiated derivatives of XEN cells, incomplete $\mathrm{iXCl}$ is more stable and is maintained more strictly (Merzouk et al., 2014). Moreover, iXCI maintenance in XEN cells and their derivatives is independent of PRC2 histone-methyltransferases. The data confirm differences in regulation of imprinted Xp silencing between extraembryonic lineages of diverse origin.

In mice, inactive $\mathrm{Xp}$ recruits the same histone modifications as Xi does in cells of somatic tissues (Chaumeil et al., 2004; Okamoto and Heard 2006). During $\mathrm{XXCl} X p$ is associated with $X$ ist RNA and enriched with PRC1 and PRC2 complexes as well as ubiquitinilated $\mathrm{H} 2 \mathrm{~A}$ and $\mathrm{H} 3 \mathrm{~K} 27$ me3 that are typical of inactive chromatin and established by the complexes. At the same time, $\mathrm{Xp}$ is depleted in histone modifications characteristic of active chromatin. In vole XEN cells, besides chromosome domains with Xist-dependent modifications, $\mathrm{Xp}$ also contains blocks of inactive chromatin similar to constitutive heterochromatin of autosomal centromeric and telomeric regions (Shevchenko et al., 2009). The inactive Xp in iXCI has long been believed to be hypomethylated. 
However, a genome wide 5-methylcytosine distribution assay revealed that during $\mathrm{iXCl}$ in mouse extraembryonic cells, DNA methylation is recruited to $X$-linked promoters and $\mathrm{CpG}$ islands at the level comparable with that during $\mathrm{XCI}$ in somatic tissues (Senner et al., 2012).

As in mice, vole inactive $\mathrm{Xp}$ demonstrates histone modification pattern similar to Xi in somatic tissues. In vole TS cells and blastocysts, Xi has a unique chromatin structure comprising Xist RNA as well as trimethylated $\mathrm{H} 3 \mathrm{~K} 9$ and $\mathrm{H} 4 \mathrm{~K} 20, \mathrm{HP} 1 \beta$ (CBX1), and $\mathrm{HP} 1 \gamma$ (CBX3) attributable to constitutive heterochromatin (Vaskova et al., 2014). Xi chromatin during $i X C l$ in voles also contains the SETDB1 histone-methyltransferase and KAP1 protein (Shevchenko et al., 2018). Polycomb proteins and H3K27me3 are observed on Xi only in differentiated trophoblast cells that arise after implantation when placenta is formed (Vaskova et al., 2014). In vole TS cells, Xist repression in the absence of PRC2 and H3K27me3 does not cause changes in chromatin modifications and global X-linked gene reactivation (Shevchenko et al., 2018). Thus, although iXCI in vole TS cells is not complete (Dementyeva et al., 2010), it is more stable (Shevchenko et al., 2018) than that in the mouse TS cells, illustrating interspecific differences in iXCI between rodents.

\section{Random X chromosome inactivation in rodents}

As shown by immunofluorescence (Mak et al., 2004; Okamoto et al., 2004) and then confirmed by single cell RNA sequencing (Borensztein et al., 2017a; Mohammed et al., 2017), starting from the middle blastocyst stage, Xp loses inactive chromatin marks and becomes reactivated in epiblast cells of the inner cell mass. The OCT4 interacting ZFHX3 transcription factor and several zinc-finger proteins rather than pluripotency factors showed correlation (positive or negative) with the Xp reactivation (Mohammed et al., 2017). Early-reactivated genes were enriched with MYC transcription factor binding sites compared to other X-linked genes (Borensztein et al., 2017a). More slowly reactivated genes were highly enriched with $\mathrm{H} 3 \mathrm{~K} 27 \mathrm{me} 3$ and their reactivation strongly correlated with the presence of NANOG and loss of Xist expression. After reactivation, two active $X$ chromosomes are maintained for a short time until epiblast cells initiate random $\mathrm{XCl}(\mathrm{rXCl})$ during implantation (Fig. 2). In the next inactivation cycle, $X p$ and $X m$ have equal chances to be silenced (Okamoto and Heard 2006). In mice, $r X C l$ is stably inherited in somatic cell generations and is retained in ontogenesis. Vole and rat somatic cells also demonstrate stable rXCI (Dementyeva et al., 2010; Shevchenko et al., 2009; Vaskova et al., 2015).

\section{$X$ chromosome counting and choice in $\mathrm{rXCl}$ of rodents}

First step in mouse $\mathrm{rXCl}$ is counting $X$ chromosome number relatively to autosomal sets. $\mathrm{rXCl}$ is triggered if cell contains more than one $X$ chromosome per diploid autosomal set. Thus, only one $\mathrm{X}$ chromosome remains active in diploid cells while the others X chromosomes are inactivated (Lee 2011). Factors involved in $\mathrm{X}$ chromosome counting may be associated with triggering monoallelic Xist expression which is a key event in $\mathrm{XCl}$ initiation. Nuclear non-coding RNA of the Jpx gene located upstream to the $X$ ist promoter is one of the candidates (Chureau et al., 2002). Jpx (also known as Enox) was found in other rodents, e.g. rats and common voles (Shevchenko et al., 2011). Jpx RNA is a dosagedependent Xist activator (Sun et al., 2013). Both a depletion of Jpx transcription by short hairpin RNAs and deletion of one of the two
$J p x$ alleles interfere with Xist RNA activation and $r X C l$ initiation in mouse female ESCs (Tian et al., 2010, Sun et al., 2013). On the contrary, additional Jpx copies even when located to autosomes activate Xist expression in male ESCs (Sun et al., 2013). Further studies showed that Jpx RNA was able to displace CTCF, transcription factor and chromatin insulator, from the Xist promoter. Xist activation appears to depend on balance between Jpx RNA and CTCF, which may be used to count number of $\mathrm{X}$ chromosomes and autosomal sets in cells. Key transcription factors of pluripotent state are likely to be other players involved in counting process as they were found to participate in direct Xist repression and Tsix activation (Navarro et al., 2008, 2010). For instance, depletion in OCT4, transcription factor responsible for pluripotency maintenance, causes $X$ ist activation on both $X$ chromosomes in mouse ESCs (Donohoe et al., 2009). Increased level of the Rnf12/RLIM ubiquitin ligase also can upregulate Xist during differentiation of cultured female pluripotent cells (Jonkers et al., 2009). Rnf12/RLIM may affect stability of transcription factors and their binding to Xist/ Tsix regulatory elements in dosage dependent manner. However, epiblast cells of postimplantation embryos show RLIM-independent rXCl (Shin et al., 2014; Wang et al., 2017). Thus, X chromosome counting mechanism is still poorly understood.

In mice, $\mathrm{Xi}$ is suggested to be chosen via transient $\mathrm{X}$ chromosome pairing that occurs in the Xist adjacent regions immediately before rXCl (Lee 2011; Masui et al., 2011). The pairing appears to make asymmetry necessary for monoallelic Xist expression triggering. Before $\mathrm{rXCl}$ initiation, Xist expression on both $\mathrm{X}$ chromosomes is repressed with a high level transcription of antisense Tsix RNA regulated by the Xite enhancer (Ogawa and Lee 2003). Tsix is believed to be randomly repressed on one of the two $X$ chromosomes during $X$ chromosome pairing affecting the Xite locus, leading to Xist upregulation and $\mathrm{rXCl}$ initiation (Lee 2011; Masui et al., 2011). However, another study showed that trans-activator RLIM, cis-acting elements surrounding Xist like Jpx and those involved in pairing events ensure Xistmonoallelic expression while $\mathrm{X}$-X pairing itself is not necessary for $\mathrm{rXCl}$ to take place (Barakat et al., 2014). In rats and voles, Tsix is also transcribed (Shevchenko et al., 2011). Its transcription is initiated in a conservative region and terminates upstream to the Xist transcription start site, which has a functional significance to repress Xist promoter via inactive chromatin formation as shown in mice (Navarro et al., 2005; Sado et al., 2005). However, in voles, the region homologous to Xite was deleted by a chromosomal rearrangement and intergenic transcription characteristic of the element was not found. Therefore, $\mathrm{rXCl}$ regulation in rodents may be at least partially taxon-specific (Shevchenko et al., 2011).

\section{Xist RNA spreading, transcriptional silencing initiation and stabilization}

After Xist activation, Xist RNA spreads along the $\mathrm{X}$ chromosome and causes $X$-linked gene transcription silencing which is Xist-dependent at early stages of rXCI (Wutz et al., 2002; Wutz and Jaenisch 2000). Xist RNA acts via recruiting proteins. To date 80 proteins are shown to interact directly or indirectly with Xist RNA and their functional role in XCI was confirmed using different methods (Przanowski et al., 2018). The proteins bind to Xist RNA in the regions of conservative microsatellite repeats denoted with Latin letters - from A to F. Some of the Xist-interacting proteins are discussed in this sub-section and listed in Table 1. 
TABLE 1

\section{PROTEINS BINDING TO XIST RNA DURING rXCI IN MICE}

\begin{tabular}{|c|c|c|c|}
\hline Protein name & Known function(s) and/or functional domain(s) & Binding region within Xist RNA & $\mathrm{XCl}$ step \\
\hline $\begin{array}{l}\text { CIZ1, } \\
\text { CDKN1A Interacting Zinc Finger Protein } 1\end{array}$ & DNA binding zinc finger protein & E-repeats, exon 7 & Xist RNA spreading and accumulation on Xi \\
\hline $\begin{array}{l}\text { hnRNPU (SAF-A), } \\
\text { Heterogeneous Nuclear Ribonucleoprotein U }\end{array}$ & $\begin{array}{l}\text { Binding nucleic acids and participation in the formation of ribo- } \\
\text { nucleoprotein complexes }\end{array}$ & central parts of exons 1 and 7 & Xist RNA spreading and accumulation on $\mathrm{Xi}$ \\
\hline $\begin{array}{l}\text { YY1, } \\
\text { YY1 Transcription Factor }\end{array}$ & $\begin{array}{l}\text { Transcription factor belonging to GLI-Kruppel class of zinc finger } \\
\text { proteins }\end{array}$ & C-repeats, exon 1 & Xist RNA spreading and accumulation on $\mathrm{Xi}$ \\
\hline $\begin{array}{l}\text { WTAP, } \\
\text { WT1 Associated Protein }\end{array}$ & A subunit of the RNA N6-methyltransferase complex & A-repeats, exon 1 & Xist-dependent transcriptional silencing \\
\hline $\begin{array}{l}\text { SPEN, } \\
\text { Split-end Family Transcriptional Repressor }\end{array}$ & $\begin{array}{l}\text { Interactions with different transcriptional repressors, RNA } \\
\text { binding }\end{array}$ & A-repeats, exon 1 & Xist-dependent transcriptional silencing \\
\hline $\begin{array}{l}\text { RBM15, } \\
\text { RNA Binding Motif Protein } 15\end{array}$ & $\begin{array}{l}\text { Split-end (SPEN) protein family member, participation in RNA } \\
\text { methylation }\end{array}$ & A-repeats, exon 1 & Xist-dependent transcriptional silencing \\
\hline $\begin{array}{l}\text { HDAC3, } \\
\text { Histone Deacetylase } 3\end{array}$ & Histone deacetylase activity, transcription repression & A-repeats, exon 1 & Xist-dependent transcriptional silencing \\
\hline $\begin{array}{l}\text { NCoR2 (SMRT), } \\
\text { Nuclear Receptor Corepressor } 2\end{array}$ & Transcriptional silencing & A-repeats, exon 1 & Xist-dependent transcriptional silencing \\
\hline $\begin{array}{l}\text { JARID2, } \\
\text { Jumonji and AT-Rich Interaction Domain } \\
\text { Containing } 2\end{array}$ & $\begin{array}{l}\text { Known as a transcriptional repressor which is able to interact } \\
\text { with PRC2 complex }\end{array}$ & A-repeats, exon 1 & Xist-dependent transcriptional silencing \\
\hline $\begin{array}{l}\text { ATRX, } \\
\text { Alpha Thalassemia/ Mental Retardation Syn- } \\
\text { drome X-Linked }\end{array}$ & Chromatin remodeler & A-repeats, exon 1 & Xist-dependent Xi chromatin modifications \\
\hline $\begin{array}{l}\text { PRC2, } \\
\text { Polycomb repressive complex } 2\end{array}$ & Chromatin modifier with histone methyltranferase activity & $\begin{array}{l}\text { A-repeats, exon } 1 \text {; } \\
\text { exon } 7\end{array}$ & Xist-dependent Xi chromatin modifications \\
\hline $\begin{array}{l}\text { PRC1, } \\
\text { Polycomb repressive complex } 1\end{array}$ & Chromatin modifier with ubiquitin ligase activity & B-repeats, exon 1 & Xist-dependent Xi chromatin modifications \\
\hline
\end{tabular}

All references are given in the text and in Przanowski et al., 2018.

At least three proteins, the $\mathrm{YY} 1$ transcription factor (Jeon and Lee 2011), hnRNPU nuclear matrix protein (also known as SAF-A) (Hasegawa et al., 2010), and $\mathrm{ClZ1}$ containing zinc finger domain (Sunwoo et al., 2017), are involved in Xist RNA spreading and accumulation on Xi. Knockdown of the genes encoding the proteins results in loss of Xist RNA clouds on Xi. Xist RNA localization on $\mathrm{Xi}$ is also disrupted when $\mathrm{CIZ1}$ is overexpressed. $\mathrm{YY} 1$ is shown to interact with C-repeats localized in the Xist exon 1 (Jeon and Lee 2011; Sarma et al., 2010). hnRNPU has DNA-binding (SAF) and RNA-binding (RGG) domains interacting with Xi DNA and Xist RNA in the central parts of exons 1 and 7 (Hasegawa et al., 2010; Yamada et al., 2015). CIZ1 binds to E-repeats in exon 7 (Sunwoo et al., 2017). 3D-SIM super-resolution microscopy demonstrated that Xist RNA was located mainly in perichromatin space of $\mathrm{Xi}$ co-localizing with nuclear matrix proteins (Cerase et al., 2014; Hasegawa et al., 2010; Smeets et al., 2014).

A-repeats of Xist RNA are known as a domain involved in transcriptional silencing (Wutz et al., 2002). A-repeats were shown to interact with several RNA-binding proteins, namely RBM15, WTAP, SPEN, ATRX, and JARID2 (rewieved in Pinter 2016). The domain also binds HDAC3 histone deacetylase, Polycomb repressive complex 2 (PRC2) with histone methyltransferase activity, as well as NCoR2 (or SMRT) which are components of a co-repressive complex. Mechanisms of transcription silencing initiation are unknown. However, WTAP RNA-methyltransferase as well as RBM15 and SPEN proteins that are able to link long non-coding RNA with chromatin and transcription regulators were found to play essential role in X-linked gene repression (Moindrot et al., 2015). HDAC3 and NCoR2 are also involved (McHugh et al., 2015). SPEN is thought to be an intermediator protein that links $X i s t$ RNA, the NCoR2 co-repressor complex, and HDAC3. Expression of evolutionary young transcriptionally active retrotransposones of the LINE-1 family was found on Xi during mouse ESC differentiation
(Chow et al., 2010). Transcribed LINEs were supposed to facilitate spreading of the inactive state increasing chromatin accessibility for repressing factors.

After silencing initiation, inactive state of $\mathrm{Xi}$ genes is maintained through covalent histone modifications and becomes Xistindependent (Wutz et al., 2002; Wutz and Jaenisch 2000). Histone modifications are established by chromatin repressive complexes PRC1 and PRC2 that also can bind Xist RNA (Pintacuda et al., 2017; Sarma et al., 2014; Zhao et al., 2008). B-repeats of Xist RNA recruit the hnRNPK RNA-binding protein interacting with the PCGF3/5-PRC1 complex (Pintacuda et al., 2017). PRC2 interacts with Xist RNA in the region of A-repeats through ATRX (Sarma et al., 2014). However, A-repeats are not the only Xist RNA domain capable to bind PRC2 (Wutz et al., 2002; Zhao et al., 2008). PRC1 and PRC2 establish Xist-dependent Xi chromatin modifications monoubiquitinilated $\mathrm{H} 2 \mathrm{AK} 119$ and $\mathrm{H} 3 \mathrm{~K} 27$ me3. Other proteins and chromatin modifications further appear on $\mathrm{Xi}$ but their recruitment does not depend on Xist RNA. MacroH2A, the ASH2I trithorax protein, CDYI, DNA hypermethylation of gene promoter regions, the DNMT3b de novo DNA methyltransferase, as well as SMCHD1 and LRF1 (or HBiX1) proteins responsible for chromatin compaction are also detected on Xi (rewieved in Moindrot and Brockdorff 2016). Thus, $X$ chromosome inactive state stabilizes and the stage of $r X C l$ maintenance begins.

Xi chromosome territory is organized concurrently with transcriptional repression. Repeated DNA sequences form inner core of the chromosome territory while inactivated genes are located outside (Chaumeil et al., 2006; Clemson et al., 2006). Correct localization of inactive genes is controlled by A-repeats of Xist RNA (Chaumeil et al., 2006). The Xi chromosome territory is coated with Xist RNA and depleted in RNA Polll. In somatic cells, genes escaping $\mathrm{XCl}$ including Xist are localized on the edge of the chromosome territory or outside. High resolution chromatin conformation capture 
technique demonstrated that $\mathrm{Xa}$ was organized in numerous topologically associated domains (Nora et al., 2012). In contrast to $\mathrm{Xa}, \mathrm{Xi}$ condensed chromatin was divided into two giant loops (up to $77 \mathrm{Mb}$ each) that were organized in two macrostructures called superdomains (Deng et al., 2015).

$\mathrm{rXCl}$ affects majority of X-linked genes and is stably maintained in cell generations. In rodents, $\mathrm{rXCl}$ is generally more complete and stable compared to iXCI (Berletch et al., 2011; Dementyeva et al., 2010). In mice, just about $3 \%$ of X-linked genes escape $\mathrm{rXCl}$ (Berletch et al., 2011) and seem to be protected from repressive chromatin modifications associated with transcriptional silencing.

\section{Modeling of $\mathrm{rXCl}$ and $\mathrm{Xi}$ reactivation in mice and rats using pluripotent stem cells}

ESCs derived from blastocyst inner cell mass as well as induced pluripotent stem cells (iPSCs) generated from somatic cells via overexpression of the OCT4, SOX2, KLF4, and c-MYC transcription factors are model systems to study $\mathrm{rXCl}$ ex vivo in mice (Barakat and Gribnau 2010). Mouse ESCs and iPSCs maintain two active $X$ chromosomes. One of the $X$ chromosomes passes all the $\mathrm{rXCl}$ stages upon ESC and iPSC differentiation with the dynamics similar to that in the cell of postimplantation embryos (Pinter 2016). Nevertheless, in differentiated derivatives of ESCs and iPSCs, Xi inactive state is maintained as in embryonic cells but not as in adult somatic cells.

Technology of somatic cell reprogramming to the pluripotent state allowed studying $X$ chromosome reactivation process in mice (Pasque et al., 2014). $X$ chromosome reactivation is a late event during reprogramming and is triggered only after establishing pluripotent state. This is in accordance with the fact that the OCT4, NANOG, and SOX2 pluripotency factors act as Xist repressors. Epigenetic changes during $X$ chromosome reactivation mainly occur with the dynamics opposite to that during $\mathrm{XCl}$ with some exception, e.g. DNA methylation. Under reprogramming, Xi acquires some traits attributable to early embryonic development. For example, PRC2 complex which appears on Xi at embryonic stages of $\mathrm{rXCl}$ and is lost in adult somatic cells, is detected on $\mathrm{Xi}$ after the mesenchymal-to-epithelial transition step of reprogramming and maintained until pluripotency gene activation. Key events to initiate $\mathrm{X}$ chromosome reactivation are loss of Xist expression and DNA demethylation. Xist repression and biallelic Tsix expression in XX iPSCs strongly correlate with NANOG upregulation. However, X-linked gene reactivation occurs only in a subset of NANOG positive cells that also express DPPA4 and PECAM1 factors. DNA hypermethylation which is the latest event on $\mathrm{Xi}$ in $\mathrm{rXCl}$ is removed during $\mathrm{X}$-reactivation just at the final stage of reprogramming to the pluripotent state. Successful pluripotency acquisition and $X$ chromosome reactivation in iPSCs require expression of PRDM14 known as a driver of active DNA demethylation (Payer et al., 2013). It is worth noting that pluripotency factors and PRDM14 are important for $X$ chromosome reactivation not only in vitro but also in vivo in primordial germ cells.

Presence of two Xa is also an obligatory property of pluripotent state in rat ESCs and iPSCs (Vaskova et al., 2015). When generated rat iPSCs $X$ chromosome inactivated in original somatic cells is reactivated. $X$ chromosome loses modifications characteristic of inactive state and restores active chromatin marks and gene expression. Loss of pluripotency during rat ESC and iPSC differentiation is accompanied by $\mathrm{rXCl}$ similar in dynamics of epigenetic events to that in mice. However, detailed studies of $\mathrm{rXCl}$ mechanisms in rat pluripotent stem cells need to be performed.

\section{$\mathrm{X}$ chromosome inactivation in other eutherian mammals}

Xi in eutherian somatic tissues has a number of common features that appear to correspond to general fundamental mechanisms underlying XCI (Moindrot and Brockdorff 2016; Pinter 2016; Przanowski et al., 2018). At the cytological level, $\mathrm{Xi}$ is detected as a dense chromatin spot (called Barr body) in female interphase nuclei. Xi replicates in late S-phase, is coated with Xist RNA and depleted in acetylated $\mathrm{H} 3$ and $\mathrm{H} 4$ histones associated with active transcription. RNA Polll is almost completely excluded from Xi chromosome territory in interphase nuclei. In humans and cattle, two types of facultative heterochromatin were identified on Xi (Chadwick and Willard 2004; Coppola et al., 2008). Some Xi domains contain XistRNAand Xist-dependent chromatin modifications such as ubiquitinilated $\mathrm{H} 2 \mathrm{~A}$ and $\mathrm{H} 3 \mathrm{~K} 27 \mathrm{me} 3$. The others are characterized by HP1, H3K9me3, and H4K20me3 attributable to constitutive heterochromatin. However, in elephants as in mice, $\mathrm{Xi}$ is not enriched with H3K9me3 and H4K20me3 (Chaumeil et al., 2011).

About $15 \%$ of human X-linked genes escape XCl (Berletch et al., 2011; Carrel and Willard 2005). Other $10 \%$ of X-linked genes have a heterogeneous expression: the genes are inactivated in most cases but can be expressed on Xi in some cells or individuals. $X i$ reactivation especially for $X$-linked genes with heterogeneous expression may be observed with age. The reactivation coincides with decreasing in Xist expression and may result in autoimmune, oncological, and age-related diseases depending on number and set of reactivated genes (Dunford et al., 2017; Forsdyke 2009; Ostan et al., 2016; Silva et al., 2008; Spatz et al., 2004). Some diseases may be due to changes in expression of genes escaping $\mathrm{XCl}$ that are sensible to Xist RNA level.

Xist and its spliced transcripts were found in many eutherians including evolutionary ancient species (Chureau et al., 2002; Elisaphenko et al., 2008). Xist nucleotide sequence, exon-intron structure, and size of processed transcript have evolved significantly. Nevertheless, the A-F minisatellite repeats that act as Xist RNA functional domains in mice were identified in all the eutherian species studied despite divergence in the evolution. Thus, Xist is likely to be a key gene during $\mathrm{XCl}$ in eutherian mammals.

However, mechanisms of $\mathrm{XCl}$ initiation in early embryogenesis may differ among mammals (Fig. 2). In contrast to mice, Xistexpression is not imprinted in human and rabbit embryos (Okamoto et al., 2011). Moreover, in humans, rabbits, horses, and mules choice of $\mathrm{X}$ chromosome for inactivation is random in both embryo proper and extraembryonic tissues (Okamoto et al., 2011; Wang et al., 2012). $\mathrm{XCl}$ is triggered later in development compared to mice, so time point of $\mathrm{XCl}$ initiation varies between species (Okamoto et al., 2011).

In rabbit female embryos, Xist RNA accumulation occurs at the early blastocyst stage (Okamoto et al., 2011). Surprisingly, about one half of blastomeres shows biallelic Xist expression and inactivation of an X-linked gene, Hprt1. By the late blastocyst stage, majority of blastocyst cells have only one Xi expressing Xist. How initial biallelic Xist expression is settled down is still unclear. As no differences in cell death were observed between male and female rabbit blastocysts, one may suggest that $\mathrm{XCl}$ is reversed on one of the two $\mathrm{X}$ chromosomes or cells carrying $\mathrm{Xa}$ and $\mathrm{Xi}$ have selective 
Fig. 2. Diverse strategies of $X$ chromosome inactivation in mice and humans. In mice, $\mathrm{XCl}$ initiates at the 4-cell stage. XCl is imprinted and Xist is expressed exclusively on Xp. Xist RNA gradually spreads along $X p$ and induces gene silencing. The process is completed by the blastocyst stage. In epiblast of late blastocyst, $\mathrm{Xp}$ is reactivated and subsequent $\mathrm{XCl}$ is random. In trophectoderm, $\mathrm{XCl}$ retains imprinted but degree of gene silencing is reducing with time. In humans, XIST expression initiates later, at the 8-cell stage, on both X chromosomes. X-linked genes are biallelically expressed but their expression level is reduced. The transcriptional damping may be due to interaction of XIST RNA and its antagonist, XACT RNA. XCl is established only at postimplantation stages and it is at once random. $X m$ and $X p$, maternal and paternal $X$ chromosomes; $X a$ and $X i$, active and inactive $X$ chromosomes; $X \mathrm{Cl}, X$ chromosome inactivation; iXCl, imprinted $X$ chromosome inactivation; $T E$, trophectoderm.

advantage compared to cells with two Xi.

In human preimplantation development, $X I S T$ transcript is detected from the 8-cell to blastocyst stages on the only X chromosome in males and both $X$ chromosomes in females (Okamoto et al., 2011) (Fig. 2). The fact that $X I S T$ is activated in both males and females suggests that $X I S T$ expression is not sensitive to $X$ chromosome number, at least at initial stages. In comparison with somatic tissues, XISTRNAclouds in human embryos seem diffuse. Another non-coding RNAis accumulated simultaneously with XISTexpression on active $X$ chromosomes in ESCs and early embryos (Vallot et al., 2017). The RNA is transcribed from the $X A C T$ gene which is located several megabases from the XIST locus. XACT transcript can disturb XISTRNA association with $\mathrm{X}$ chromosome and its capacity to initiate $\mathrm{XCl}$ (Vallot et al., 2015, 2017). This may lead to $X I S T$ RNA diffuse localization. XACT is not conserved in mammals. It was not found in mice and appears to function only in primates. Biallelic expression is characteristic not only of XIST and XACT but also of other X-linked genes (Patel et al., 2017). Studies of rhesus macaques demonstrated as well Xist expression in blastocysts of both sexes and biallelic expression of Xist and other X-linked genes in females (Tachibana et al., 2012).

It was suggested that a process of $\mathrm{X}$-linked gene dosage compensation different from classical $\mathrm{XCl}$ had to occur in early development of humans and other primates. RNA sequencing of single blastomeres of female preimplantation embryos evidences for decreasing in gene transcription on both $X$ chromosomes, which was termed transcriptional damping (Fig. 2) (Petropoulos et al., 2016; Sahakyan and Plath 2016). Possible mechanisms of the phenomenon may be based on XIST and XACT RNA antagonism. XIST RNA interacting with WTAP15, RBM15, SPEN2, etc. decreases gene transcription and initiates their inactivation.

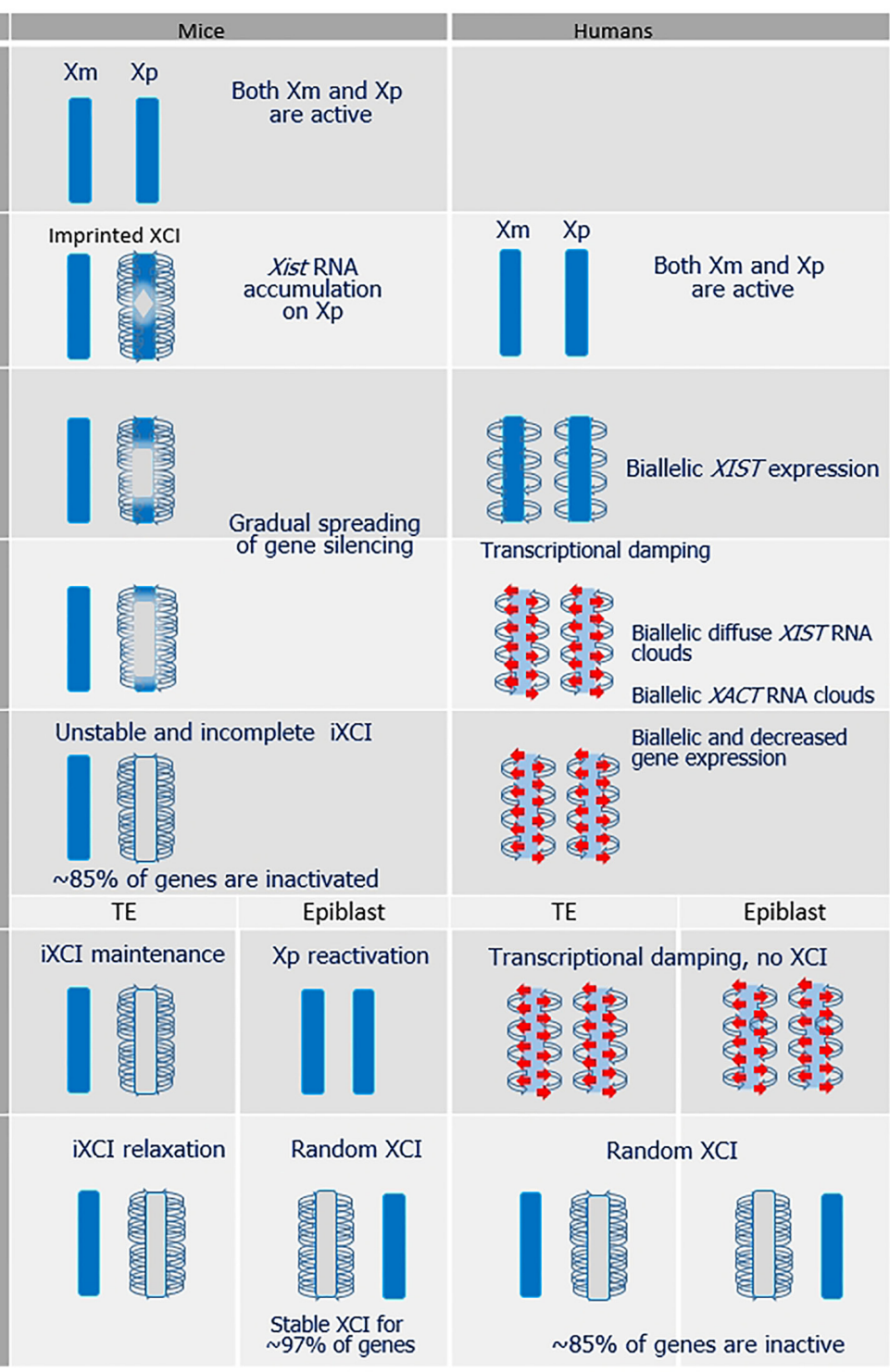

$-\mathrm{xa}$

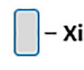

$-\mathrm{X}$ with decreased transcription

At the same time, XACT RNA eliminates the effect not allowing $\mathrm{XCl}$ to be stabilized and to become irreversible. However, it is still unclear why transcriptional damping is not detected in male embryos where XIST and XACT RNA are also co-localized on Xa. Another study argues the idea of transcriptional damping. In early embryogenesis, decreasing in biallelic expression and subsequent increasing in monoallelic expression were observed, which was in accordance with classical conception of $\mathrm{rXCl}$ (Moreira de Mello et al., 2017). Moreover, active $X$ chromosomes were upregulated in human ESCs and early development. As XCI takes place quite late in human embryonic development (probably after implantation) and choice of $X$ chromosome for inactivation is random at once, $X$ chromosome reactivation and subsequent $\mathrm{XCl}$ are not required. It is worth noting that the absence of $\mathrm{XCl}$ in trophectoderm of human blastocyst may imply that dosage compensation is not essential at this stage. 
In eutherians, Xistexpression regulation appears to be speciesspecific, which may underlie interspecific differences in XCl initiation time, mechanisms of $X$ chromosome counting and choice. Pluripotency factors repressing Xist in mice allow its biallelic expression in rabbits and humans (Okamoto et al., 2011). Moreover, antisense Tsix transcription regulating random monoallelic Xist expression in mice is poorly retained or even is absent in other mammals (Lee 2011). Although TSIX/Tsix was found in humans and cattle, it is transcribed from Xi simultaneously with XIST/Xist in fetus and placenta (Farazmand et al., 2004; Migeon et al., 2002). This means that TSIX/Tsix function is not preserved in humans and other mammals. Moreover, new non-coding RNAs might arise to regulate $X i s t$ expression like $X A C T$ RNA in primates. Another two non-coding RNAs, Ftxand Jpx (Enox), regulating Xistexpression in mice are preserved and expressed in humans and cattle (Chureau et al., 2002) and may function at early stages of XCl. However, in humans, $\mathrm{X}$ chromosome counting depends mainly on autosomal factors but not on expression of X-linked sequences like Rnf12 and $J p x$ as in mice. Presence of two Xa in human triploid cells $(69, X X X$ and $69, X X Y)$ suggests that three copies of certain autosomes are able to maintain two $X$ chromosome in the active state via encoding a dosage-sensitive XIST repressor (Migeon 2017). The repressor is likely to be located to chromosomes 1 and 19.

Pluripotent stem cells (PSCs) - ESCs and iPSCs - have been generated for many mammalian species (Ezashi et al., 2016). Nevertheless, besides rodents, $\mathrm{X}$ chromosome epigenetic status, $\mathrm{XCI}$, and $\mathrm{XCU}$ were studied in human PSCs only. Human PSCs $(46, X X)$ have a heterogeneous $X$ chromosome epigenetic status which is not stable and can be changed during cultivation (Anguera et al., 2012; Silva et al., 2008). A few human PSC lines are able to trigger inactivation of one of the two $X$ chromosomes upon differentiation like mouse and rat PSCs. Most 46,XX PSC lines demonstrate inactivation of one of the two $X$ chromosomes in the pluripotent state. However, $\mathrm{Xi}$ inactive state degrades rapidly or undergoes erosion during cultivating human PSCs. The erosion on $\mathrm{Xi}(\mathrm{Xe})$ is characterized by irreversible loss of XIST expression and H3K27me3, depletion in DNA methylation, and gene reactivation (Anguera et al., 2012; Silva et al., 2008; Vallot et al., 2015). Xe epigenetic state remains irreversible, is transmitted into differentiated derivatives and is maintained under reprogramming of the derivatives to the pluripotent state. The difference in Xe state is obvious on the transcriptional level. In PSCs, genes are expressed along the entire Xe but transcription level from Xe is much lower than that from Xa. In differentiated derivatives, Xa transcripts are predominately detected and just several genes are expressed on $\mathrm{Xe}$ (Vallot et al., 2015). Cells carrying two Xa, Xa and Xi, or Xa and Xe may be often present in the same PSC culture, especially at early passages (Patel et al., 2017). When cultivated percentage of cells with $\mathrm{Xe}$ is increasing and can reach $100 \%$. In comparison with PSCs carrying two Xa or Xa and Xi, PSCs bearing Xe and losing capacity to express XIST are shown to have an elevated expression level of X-linked oncogenes and other genes associated with cancer (Anguera et al., 2012; Silva et al., 2008). The erosion may result from de novo expression of $X A C T$ RNA on $\mathrm{Xi}$. In PSCs, XACT RNA normally spreads along $X a$ and seems to be localized at the same loci on Xi as XIST RNA (Vallot et al., 2015). During erosion, XACTRNA is believed to dislodge XISTRNA from $\mathrm{Xi}$, which causes loss of XIST-dependent repressive chromatin modifications, gene reactivation, and complete XIST repression.
Influence of human PSC cultivation conditions on X chromosome status has been postulated. Some of the conditions are thought to promote $\mathrm{Xi}$ reactivation and maintenance of two Xa (Hanna et al., 2010; Hasegawa et al., 2014). However, it is still unclear if $X$ chromosome reactivation was really detected because the authors could observe XCl erosion also accompanied with XIST repression, loss of XIST-dependent repressive chromatin modifications, and Xi gene reactivation. It is obvious that unstable $X$ chromosome status and its possible negative consequences prevent human PSCs and their differentiated derivatives from using in biomedical studies and clinical regenerative medicine. To solve the problem, approaches to control X chromosome status in PSCs and to make PSCs similar to blastocyst cells are being developed. Researchers are trying to generate and cultivate human PSCs in so called naïve pluripotency state that corresponds to cells of preimplantation blastocysts. Some protocols provide generating and maintenance of ESCs corresponding to human preimplantation embryos in gene expression (Huang et al., 2014). One of the methods, 5iLAF, based on using inhibitors of the MEK, B-RAF, GSK3b, SRC, and RHO kinases as well as the LIF, Activin A, and FGF2 growth factors restores biallelic $X I S T$ expression in ESCs. In differentiated derivatives of the ESCs, XIST-dependent XCI is reproduced (Sahakyan et al., 2017). One may expect that naïve pluripotent ESCs derived by the protocol will allow verifying transcriptional damping of $X$-linked genes and studying $\mathrm{XCI}$ mechanisms in humans. Arecent study of mouse ESCs and embryos showed that exit from naïve pluripotent state at the onset of differentiation caused Xist accumulation accompanied by transient chromatin repression and partial $X$-linked gene silencing on male and both female $X$ chromosomes (Sousa et al., 2018). The result makes the $\mathrm{XCl}$ story more complicated and suggests that some interspecific differences in $\mathrm{rXCl}$ between human and rodents might arise from manipulations with naïve plupipotency gene network caused, for instance, by culture conditions. The facts that counting and choice between the two $\mathrm{X}$ chromosomes are not necessary for $\mathrm{XCl}$ initiation in mice as well as $\mathrm{XCl}$ initiation and spreading also occur in males make us realize $\mathrm{XCI}$ mechanisms are still poorly understood and many questions on the process regulation need to be clarified.

\section{Conclusion}

In mammals, dosage compensation takes place in early embryonic development. It is closely linked with pluripotent cells and their differentiation and represents an important model to study epigenetic transcription regulation. However, mechanisms of dosage compensation of mammalian sex chromosomes demonstrate high plasticity and rapidly adapt to evolutionary changes in early development. In spite of significant progress that has been made in our understanding of mammalian X-linked gene dosage compensation, numerous aspects of the phenomenon remain unclear and need to be further investigated. Forthcoming results allow clarifying reasons and mechanisms underlying human diseases caused by imbalance of $\mathrm{X}$-linked gene expression and developing new approaches to X-linked disease therapy.

\section{Acknowledgments}

The work was funded by the Program of fundamental studies of Presidium of the Russian Academy of Sciences "Fundamental studies for biomedicaltechnologies"(I.2.42), project № 0324-2018-0029. We apologize 
to all authors whose studies were not cited due to the strict limitation of reference number.

\section{References}

ANGUERA MC, SADREYEV R, ZHANG Z, SZANTO A, PAYER B, SHERIDAN SD, KWOK S, HAGGARTY SJ, SUR M, ALVAREZ J, GIMELBRANT A, MITALIPOVA M, KIRBY JE, LEE JT (2012). Molecular signatures of human induced pluripotent stem cells highlight sex differences and cancer genes. Cell Stem Cell 11: 75-90.

BARAKAT TS, GRIBNAU J (2010). X chromosome inactivation and embryonic stem cells. In Springer, Boston, MA, pp. 132-154.

BARAKAT TS, LOOS F, VAN STAVEREN S, MYRONOVA E, GHAZVINI M, GROOTEGOED JA, GRIBNAU J (2014). The trans-activator RNF12 and cis-acting elements effectuate $\mathrm{X}$ chromosome inactivation independent of $\mathrm{X}$-pairing. $\mathrm{Mol}$ Cell 53: 965-978.

BERLETCH JB, YANG F, XU J, CARREL L, DISTECHE CM (2011). Genes that escape from $X$ inactivation. Hum Genet 130: 237-245.

BORENSZTEIN M, OKAMOTO I, SYX L, GUILBAUD G, PICARD C, ANCELIN K, GALUPA R, DIABANGOUAYA P, SERVANT N, BARILLOTE, SURANI A, SAITOU M, CHEN C-J, ANASTASSIADIS K, HEARD E (2017a). Contribution of epigenetic landscapes and transcription factors to $\mathrm{X}$-chromosome reactivation in the inner cell mass. Nat Commun 8: 1297.

BORENSZTEIN M, SYX L, ANCELIN K, DIABANGOUAYA P, PICARD C, LIU T, LIANG J-B, VASSILEV I, GALUPA R, SERVANT N, BARILLOT E, SURANI A, CHEN C-J, HEARD E (2017b). Xist-dependent imprinted $X$ inactivation and the early developmental consequences of its failure. Nat Struct Mol Biol 24: 226-233.

CALABRESE JM, SUN W, SONG L, MUGFORD JW, WILLIAMS L, YEED, STARMER J, MIECZKOWSKI P, CRAWFORD GE, MAGNUSONT (2012). Site-specific silencing of regulatory elements as a mechanism of $X$ inactivation. Cell 151: 951-963.

CARREL L, WILLARD HF (2005). X-inactivation profile reveals extensive variability in X-linked gene expression in females. Nature 434: 400-404.

CERASEA, SMEETS D, TANG YA, GDULAM, KRAUS F, SPIVAKOV M, MOINDROT B, LELEU M, TATTERMUSCH A, DEMMERLE J, NESTEROVA TB, GREEN C OTTE AP, SCHERMELLEH L, BROCKDORFF N (2014). Spatial separation of Xist RNA and Polycomb proteins revealed by superresolution microscopy. Proc Natl Acad Sci USA 111: 2235-2240.

CHADWICK BP, WILLARD HF (2004). Multiple spatially distinct types of facultative heterochromatin on the human inactive X chromosome. Proc Natl Acad Sci USA 101: 17450-17455.

CHAUMEIL J, LE BACCON P, WUTZA, HEARD E (2006). A novel role for Xist RNA in the formation of a repressive nuclear compartment into which genes are recruited when silenced. Genes Dev 20: 2223-2237.

CHAUMEIL J, OKAMOTO I, HEARD E (2004). X-chromosome inactivation in mouse embryonic stem cells: analysis of histone modifications and transcriptional activity using immunofluorescence and FISH. In Method. Enzymol. pp. 405-419.

CHAUMEIL J, WATERS PD, KOINA E, GILBERT C, ROBINSON TJ, GRAVES JAM (2011). Evolution from XIST-independent to XIST-controlled X-chromosome inactivation: epigenetic modifications in distantly related mammals. PLoS One6: e19040.

CHEN X, ZHANG J (2015). No X-chromosome dosage compensation in human proteomes. Mol Biol Evol 32: 1456-1460.

CHOW JC, CIAUDO C, FAZZARI MJ, MISE N, SERVANTN, GLASS JL, ATTREED M, AVNER P, WUTZA, BARILLOT E, GREALLY JM, VOINNET O, HEARD E (2010). LINE-1 activity in facultative heterochromatin formation during $X$ chromosome inactivation. Cell 141: 956-969.

CHUREAU C, PRISSETTE M, BOURDET A, BARBE V, CATTOLICO L, JONES L, EGGEN A, AVNER P, DURET L (2002). Comparative sequence analysis of the $X$ inactivation center region in mouse, human, and bovine. Genome Res 12:894-908.

CLEMSON CM, HALL LL, BYRON M, MCNEIL J, LAWRENCE JB (2006). The $X$ chromosome is organized into a gene-rich outer rim and an internal core containing silenced nongenic sequences. Proc Natl Acad Sci USA 103: 7688-7693.

COPPOLA G, PINTON A, JOUDREY EM, BASRUR PK, KING WA (2008). Spatial distribution of histone isoforms on the bovine active and inactive $X$ chromosomes. Sex Dev 2: 12-23.

CORBEL C, DIABANGOUAYA P, GENDREL A-V, CHOW JC, HEARD E (2013). Unusual chromatin status and organization of the inactive $\mathrm{X}$ chromosome in murine trophoblast giant cells. Development 140: 861-872.
DEMENTYEVA EV, SHEVCHENKO AI, ANOPRIYENKO OV, MAZUROK NA, ELISAPHENKO EA, NESTEROVA TB, BROCKDORFF N, ZAKIAN SM (2010). Difference between random and imprinted $X$ inactivation in common voles. Chromosoma 119: 541-552.

DEMENTYEVA EV, SHEVCHENKO AI, ZAKIAN SM (2009). X-chromosome upregulation and inactivation: two sides of the dosage compensation mechanism in mammals. Bioessays 31: 21-28.

DENG Q, RAMSKÖLD D, REINIUS B, SANDBERG R (2014). Single-cell RNA-seq reveals dynamic, random monoallelic gene expression in mammalian cells. Science 343: 193-196.

DENG X, BERLETCH JB, MA W, NGUYEN DK, HIATT JB, NOBLE WS, SHENDURE J, DISTECHE CM (2013). Mammalian X upregulation is associated with enhanced transcription initiation, RNA half-life, and MOF-mediated H4K16 acetylation. Dev Cell 25: 55-68.

DENG X, BERLETCH JB, NGUYEN DK, DISTECHE CM (2014). X chromosome regulation: diverse patterns in development, tissues and disease. Nat Rev Genet 15: $367-378$

DENG X, HIATT JB, NGUYENDK, ERCANS, STURGILLD, HILLIERLW, SCHLESINGER F, DAVIS CA, REINKE VJ, GINGERAS TR, SHENDURE J, WATERSTON RH, OLIVER B, LIEB JD, DISTECHE CM (2011). Evidence for compensatory upregulation of expressed $\mathrm{X}$-linked genes in mammals, Caenorhabditis elegans and Drosophila melanogaster. Nat Genet 43: 1179 - 1185.

DENG X, MA W, RAMANI V, HILL A, YANG F, AY F, BERLETCH JB, BLAU CA, SHENDURE J, DUAN Z, NOBLE WS, DISTECHE CM (2015). Bipartite structure of the inactive mouse X chromosome. Genome Biol 16:152. doi: 10.1186/ s13059-015-0728-8

DONOHOE ME, SILVA SS, PINTER SF, XU N, LEE JT (2009). The pluripotency factor OCT4 interacts with CTCF and also controls X-chromosome pairing and counting. Nature 460: 128-132.

DUNFORDA, WEINSTOCKDM, SAVOVAV, SCHUMACHER SE, CLEARY JP, YODA A, SULLIVAN TJ, HESS JM, GIMELBRANT AA, BEROUKHIM R, LAWRENCE MS, GETZ G, LANE AA (2017). Tumor-suppressor genes that escape from Xinactivation contribute to cancer sex bias. Nat Genet 49: 10-16.

ELISAPHENKO EA, KOLESNIKOV NN, SHEVCHENKO AI, ROGOZIN IB, NESTEROVA TB, BROCKDORFF N, ZAKIAN SM (2008). A dual origin of the Xist gene from a protein-coding gene and a set of transposable elements. PLoSOne3:e2521.

EZASHI T, YUAN Y, ROBERTS RM (2016). Pluripotent stem cells from domesticated mammals. Annu Rev Anim Biosci 4: 223-253.

FARAZMAND A, BASRUR PK, STRANZINGER G, GRAPHODATSKAYAD, REYES ER, KING WA (2004). Expression of XIST sense and antisense in bovine fetal organs and cell cultures. Chromosome Res 12: 275-283.

FAUCILLION M-L, LARSSON J (2015). Increased expression of X-linked genes in mammals is associated with a higher stability of transcripts and an increased ribosome density. Genome Biol Evol 7: 1039-1052.

FORSDYKE DR (2009). X chromosome reactivation perturbs intracellular self/not-self discrimination. Immunol Cell Biol 87: 525-528.

HANNA J, CHENG AW, SAHA K, KIM J, LENGNER CJ, SOLDNER F, CASSADY JP, MUFFAT J, CAREY BW, JAENISCH R (2010). Human embryonic stem cells with biological and epigenetic characteristics similar to those of mouse ESCs. Proc Natl Acad Sci USA 107: 9222-9227.

HASEGAWA Y, BROCKDORFF N, KAWANO S, TSUTUI K, TSUTUI K, NAKAGAWA $S$ (2010). The matrix protein hnRNP $U$ is required for chromosomal localization of Xist RNA. Dev Cell 19: 469-476.

HASEGAWAY, TANG D, TAKAHASHI N, HAYASHIZAKI Y, FORREST ARR, SUZUKI $H$ (2014). CCL2 enhances pluripotency of human induced pluripotent stem cells by activating hypoxia related genes. Sci Rep 4: 5228.

HEMBERGER M, KURZ H, ORTH A, OTTO S, LÜTTGES A, ELLIOTT R, NAGY A, TAN SS, TAM P, ZECHNER U, FUNDELE RH (2001). Genetic and developmental analysis of $X$-inactivation in interspecific hybrid mice suggests a role for the $Y$ chromosome in placental dysplasia. Genetics 157: 341-348.

HUANG K, MARUYAMA T, FAN G (2014). The naive state of human pluripotent stem cells: a synthesis of stem cell and preimplantation embryo transcriptome analyses. Cell Stem Cell 15: 410-415.

INOUE A, JIANG L, LU F, ZHANG Y (2017). Genomic imprinting of Xist by maternal H3K27me3. Genes Dev 31:1927-1932.

JEON Y, LEE JT (2011). YY1 tethers Xist RNA to the inactive $X$ nucleation center. 
Cell 146: 119-133.

JONKERS I, BARAKAT TS, ACHAME EM, MONKHORST K, KENTER A, RENTMEESTER E, GROSVELD F, GROOTEGOED JA, GRIBNAU J (2009). RNF12 is an $\mathrm{X}$-encoded dose-dependent activator of $\mathrm{X}$ chromosome inactivation. Cell 139: 999-1011.

JULIEN P, BRAWAND D, SOUMILLON M, NECSULEA A, LIECHTI A, SCHÜTZ F, DAISH T, GRÜTZNER F, KAESSMANN H (2012). Mechanisms and evolutionary patterns of mammalian and avian dosage compensation. PLoSBiol10: e1001328.

KALANTRY S, MILLS KC, YEE D, OTTE AP, PANNING B, MAGNUSON T (2006). The Polycomb group protein Eed protects the inactive $\mathrm{X}$-chromosome from differentiation-induced reactivation. Nat Cell Biol 8: 195-202.

LEE JT (2000). Disruption of imprinted $X$ inactivation by parent-of-origin effects at Tsix. Cell 103: 17-27.

LEE JT (2011). Gracefully ageing at 50, X-chromosome inactivation becomes a paradigm for RNA and chromatin control. Nat Rev Mol Cell Biol 12: 815-826.

LIN H, GUPTA V, VERMILYEA MD, FALCIANI F, LEE JT, O'NEILL LP, TURNER BM (2007). Dosage compensation in the mouse balances up-regulation and silencing of X-linked genes. PLoS Biol 5: e326.

LIN H, HALSALL JA, ANTCZAK P, O'NEILL LP, FALCIANI F, TURNER BM (2011). Relative overexpression of $X$-linked genes in mouse embryonic stem cells is consistent with Ohno's hypothesis. Nat Genet 43: 1169-1170.

LYON MF (1961). Gene action in the X-chromosome of the mouse (Mus musculus L.). Nature 190: 372-373.

MACLARY E, BUTTIGIEG E, HINTEN M, GAYEN S, HARRIS C, SARKAR MK, PURUSHOTHAMAN S, KALANTRY S (2014). Differentiation-dependent requirement of Tsix long non-coding RNA in imprinted X-chromosome inactivation. Nat Commun 5: 4209.

MAK W, NESTEROVA TB, DE NAPOLES M, APPANAH R, YAMANAKAS, OTTE AP, BROCKDORFF N (2004). Reactivation of the paternal $X$ chromosome in early mouse embryos. Science 303: 666-669.

MARAHRENS Y, PANNING B, DAUSMAN J, STRAUSS W, JAENISCH R (1997). Xist-deficient mice are defective in dosage compensation but not spermatogenesis. Genes Dev 11: 156-166.

MASUI O, BONNET I, LE BACCON P, BRITO I, POLLEX T, MURPHY N, HUPÉ P, BARILLOT E, BELMONT AS, HEARD E (2011). Live-cell chromosome dynamics and outcome of $X$ chromosome pairing events during ES cell differentiation. Cell 145: 447-458.

MCHUGH CA, CHEN C-K, CHOW A, SURKA CF, TRAN C, MCDONEL P, PANDYAJONES A, BLANCO M, BURGHARD C, MORADIAN A, SWEREDOSKI MJ, SHISHKIN AA, SU J, LANDER ES, HESS S, PLATH K, GUTTMAN M (2015). The Xist IncRNA interacts directly with SHARP to silence transcription through HDAC3. Nature 521: 232-236.

MERZOUK S, DEUVE JL, DUBOIS A, NAVARRO P, AVNER P, MOREY C (2014). Lineage-specific regulation of imprinted $X$ inactivation in extraembryonic endoderm stem cells. Epigenetics Chromatin 7: 11.

MIGEON BR (2017). Choosing the active $X$ : the human version of $X$ inactivation. Trends Genet 33: 899-909.

MIGEON BR, LEE CH, CHOWDHURY AK, CARPENTER H (2002). Species differences in TSIX/Tsix reveal the roles of these genes in X-chromosome inactivation. Am J Hum Genet 71: 286-293.

MOHAMMED H, HERNANDO-HERRAEZI, SAVINO A, SCIALDONE A, MACAULAY I, MULAS C, CHANDRA T, VOET T, DEAN W, NICHOLS J, MARIONI JC, REIK $W$ (2017). Single-cell landscape of transcriptional heterogeneity and cell fate decisions during mouse early gastrulation. Cell Rep 20: 1215-1228.

MOINDROT B, BROCKDORFF N (2016). RNA binding proteins implicated in Xistmediated chromosome silencing. Semin Cell Dev Biol 56: 58-70.

MOINDROT B, CERASE A, COKER H, MASUI O, GRIJZENHOUT A, PINTACUDA G, SCHERMELLEH L, NESTEROVA TB, BROCKDORFF N (2015). A pooled shRNA screen identifies Rbm15, Spen, and Wtap as factors required for Xist RNA-mediated silencing. Cell Rep 12: 562-572.

MOREIRA DE MELLO JC, FERNANDES GR, VIBRANOVSKI MD, PEREIRA L V. (2017). Early $X$ chromosome inactivation during human preimplantation development revealed by single-cell RNA-sequencing. Sci Rep 7: 10794.

NAGAOKA SI, HASSOLD TJ, HUNT PA(2012). Human aneuploidy: mechanisms and new insights into an age-old problem. Nat Rev Genet 13: 493-504.
NAVARRO P, CHAMBERS I, KARWACKI-NEISIUS V, CHUREAU C, MOREY C ROUGEULLE C, AVNER P (2008). Molecular coupling of Xist regulation and pluripotency. Science 321: 1693-1695.

NAVARRO P, OLDFIELD A, LEGOUPI J, FESTUCCIA N, DUBOIS A, ATTIA M, SCHOORLEMMER J, ROUGEULLE C, CHAMBERSI, AVNERP (2010). Molecular coupling of Tsix regulation and pluripotency. Nature 468: 457-460.

NAMEKAWA SH, PAYER B, HUYNH KD, JAENISCH R, LEE JT (2010). Two-step imprinted $X$ inactivation: repeat versus genic silencing in the mouse. Mol Cell Biol 30: 3187-3205

NAVARRO P, PICHARD S, CIAUDO C, AVNER P, ROUGEULLE C (2005). Tsix transcription across the Xist gene alters chromatin conformation without affecting Xist transcription: implications for X-chromosome inactivation. Genes Dev 19: 1474-1484.

NGUYEN DK, DISTECHE CM (2006). Dosage compensation of the active X chromosome in mammals. Nat Genet 38: 47-53.

NORA EP, LAJOIE BR, SCHULZ EG, GIORGETTI L, OKAMOTO I, SERVANT N PIOLOT T, VAN BERKUM NL, MEISIG J, SEDAT J, GRIBNAU J, BARILLOT E, BLÜTHGEN N, DEKKER J, HEARD E (2012). Spatial partitioning of the regulatory landscape of the X-inactivation centre. Nature 485: 381-385.

OGAWA Y, LEE JT (2003). Xite, X-inactivation intergenic transcription elements that regulate the probability of choice. Mol Cell 11: 731-743.

OHNO S (1967). Sex chromosomes and sex-linked genes. Springer-Verlag.

OKAMOTO I, HEARD E (2006). The dynamics of imprinted $X$ inactivation during preimplantation development in mice. Cytogenet Genome Res 113: 318-324

OKAMOTO I, OTTE AP, ALLIS CD, REINBERG D, HEARD E (2004). Epigenetic dynamics of imprinted $\mathrm{X}$ inactivation during early mouse development. Science 303: 644-649.

OKAMOTO I, PATRAT C, THÉPOT D, PEYNOT N, FAUQUE P, DANIEL N, DIABANGOUAYA P, WOLF J-P, RENARD J-P, DURANTHON V, HEARD E (2011) Eutherian mammals use diverse strategies to initiate $X$-chromosome inactivation during development. Nature 472: 370-374.

OSTAN R, MONTI D, GUERESI P, BUSSOLOTTO M, FRANCESCHI C, BAGGIO G (2016). Gender, aging and longevity in humans: an update of an intriguing/ neglected scenario paving the way to a gender-specific medicine. Clin Sci (Lond) 130: 1711-1725.

PASQUE V, TCHIEU J, KARNIK R, UYEDA M, SADHU DIMASHKIE A, CASE D, PAPP B, BONORA G, PATEL S, HO R, SCHMIDT R, MCKEE R, SADO T, TADA T, MEISSNER A, PLATH K (2014). X chromosome reactivation dynamics reveal stages of reprogramming to pluripotency. Cell 159: 1681-1697.

PATEL S, BONORA G, SAHAKYAN A, KIM R, CHRONIS C, LANGERMAN J, FITZ GIBBON S, RUBBI L, SKELTON RJP, ARDEHALI R, PELLEGRINI M, LOWRY WE, CLARK AT, PLATH K (2017). Human embryonic stem cells do not change their $\mathrm{X}$ inactivation status during differentiation. Cell Rep 18: 54-67.

PAYER B, ROSENBERG M, YAMAJI M, YABUTA Y, KOYANAGI-AOI M, HAYASH K, YAMANAKA S, SAITOU M, LEE JT (2013). Tsix RNA and the germline factor, PRDM14, link X reactivation and stem cell reprogramming. Mol Cell 52: 805-818.

PESSIA E, MAKINO T, BAILLY-BECHET M, MCLYSAGHT A, MARAIS GAB (2012). Mammalian $X$ chromosome inactivation evolved as a dosage-compensation mechanism for dosage-sensitive genes on the $\mathrm{X}$ chromosome. Proc Natl Acad Sci USA 109: 5346-5351.

PETROPOULOS S, EDSGÄRD D, REINIUS B, DENG Q, PANULA SP, CODELUPPI S, REYES AP, LINNARSSON S, SANDBERG R, LANNER F (2016). Single-cell RNA-seq reveals lineage and $X$ chromosome dynamics in human preimplantation embryos. Cell 167: 285.

PINTACUDA G, WEI G, ROUSTAN C, KIRMIZITAS BA, SOLCAN N, CERASE A CASTELLOA, MOHAMMEDS, MOINDROTB, NESTEROVATB, BROCKDORFF $\mathrm{N}$ (2017). hnRNPK recruits PCGF3/5-PRC1 to the Xist RNA B-repeat to establish Polycomb-mediated chromosomal silencing. Mol Cell 68: 955-969.e10.

PINTER SF (2016). A tale of two cities: How Xist and its partners localize to and silence the bicompartmental X. Semin Cell Dev Biol 56: 19-34.

PRUDHOMME J, DUBOIS A, NAVARRO P, ARNAUD D, AVNER P, MOREY C (2015). A rapid passage through a two-active-X-chromosome state accompanies the switch of imprinted $X$-inactivation patterns in mouse trophoblast stem cells. Epigenetics Chromatin 8: 52

PRZANOWSKI P, WAŚKO U, BHATNAGAR S (2018). Novel molecular players of $X$ chromosome inactivation: new technologies and new insights. J Trans/ Genet 
Genom 2: 2.

SADO T, HOKI Y, SASAKI H (2005). Tsix silences Xist through modification of chromatin structure. Dev Cell 9: 159-165.

SAHAKYAN A, KIM R, CHRONIS C, SABRI S, BONORA G, THEUNISSEN TW, KUOY E, LANGERMAN J, CLARK AT, JAENISCH R, PLATH K (2017). Human naive pluripotent stem cells model $\mathrm{X}$ chromosome dampening and $\mathrm{X}$ inactivation. Cell Stem Cell 20: 87-101.

SANGRITHI MN, ROYO H, MAHADEVAIAH SK, OJARIKRE O, BHAW L, SESAY A, PETERS AHFM, STADLER M, TURNER JMA (2017). Non-canonical and sexually dimorphic $\mathrm{X}$ dosage compensation states in the mouse and human germline. Dev Cell 40: 289-301.e3.

SARMA K, CIFUENTES-ROJAS C, ERGUN A, DEL ROSARIO A, JEON Y, WHITE F, SADREYEV R, LEE JT (2014). ATRX directs binding of PRC2 to Xist RNA and Polycomb targets. Cell 159: 869-883.

SARMA K, LEVASSEUR P, ARISTARKHOV A, LEE JT (2010). Locked nucleic acids (LNAs) reveal sequence requirements and kinetics of Xist RNA localization to the X chromosome. Proc Natl Acad Sci USA 107: 22196-22201.

SENNER CE, KRUEGER F, OXLEY D, ANDREWS S, HEMBERGER M (2012). DNA methylation profiles define stem cell identity and reveal a tight embryonicextraembryonic lineage boundary. Stem Cells 30: 2732-2745.

SHAO C, TAKAGIN (1990). An extra maternally derived X chromosome is deleterious to early mouse development. Development 110: 969-975.

SHEVCHENKO AI, GRIGOR'EVA EV, MEDVEDEV SP, ZAKHAROVA IS, DEMENTYEVA EV, ELISAPHENKO EA, MALAKHOVA AA, PAVLOVA SV, ZAKIAN SM (2018). Impact of Xist RNAon chromatin modifications and transcriptional silencing maintenance at different stages of imprinted $\mathrm{X}$ chromosome inactivation in vole Microtus levis. Chromosoma 127: 129-139.

SHEVCHENKO AI, MALAKHOVA AA, ELISAPHENKO EA, MAZUROK NA, NESTEROVA TB, BROCKDORFF N, ZAKIAN SM (2011). Variability of sequence surrounding the Xist gene in rodents suggests taxon-specific regulation of $X$ chromosome inactivation. PLoS One 6: e22771.

SHEVCHENKO AI, PAVLOVA SV, DEMENTYEVA EV, ZAKIAN SM (2009). Mosaic heterochromatin of the inactive $X$ chromosome in vole Microtus rossiaemeridionalis. Mamm Genome 20: 644-653.

SHIN J, BOSSENZ M, CHUNG Y, MAH, BYRON M, TANIGUCHI-ISHIGAKI N, ZHU $X$, JIAO B, HALL LL, GREEN MR, JONES SN, HERMANS-BORGMEYER I, LAWRENCE JB, BACH I (2010). Maternal Rnf12/RLIM is required for imprinted X-chromosome inactivation in mice. Nature 467: 977-981.

SHINJ, WALLINGFORD MC, GALLANTJ, MARCHO C, JIAOB, BYRON M, BOSSENZ M, LAWRENCE JB, JONES SN, MAGERJ, BACHI (2014). RLIM is dispensable for $\mathrm{X}$-chromosome inactivation in the mouse embryonic epiblast. Nature 511: 86-89.

SILVA SS, ROWNTREE RK, MEKHOUBAD S, LEE JT (2008). X-chromosome inactivation and epigenetic fluidity in human embryonic stem cells. Proc Natl Acad Sci USA 105: 4820-4825.

SMEETS D, MARKAKI Y, SCHMID VJ, KRAUS F, TATTERMUSCH A, CERASE A, STERR M, FIEDLER S, DEMMERLE J, POPKEN J, LEONHARDT H, BROCKDORFF N, CREMER T, SCHERMELLEH L, CREMER M (2014). Threedimensional super-resolution microscopy of the inactive $\mathrm{X}$ chromosome territory reveals a collapse of its active nuclear compartment harboring distinct Xist RNA foci. Epigenetics Chromatin 7: 8.

SOUSA EJ, STUART HT, BATES LE, GHORBANI M, NICHOLS J, DIETMANN S, SILVAJCR (2018). Exit from naive pluripotency induces a transient X chromosome inactivation-like state in males. Cell Stem Cell 22: 919-928.e6.

SPATZ A, BORG C, FEUNTEUN J (2004). X-chromosome genetics and human cancer. Nat Rev Cancer 4: 617-629.

SUN S, DEL ROSARIO BC, SZANTO A, OGAWA Y, JEON Y, LEE JT (2013). Jpx RNA activates Xist by evicting CTCF. Cell 153: 1537-51.

SUNWOO H, COLOGNORI D, FROBERG JE, JEON Y, LEE JT (2017). Repeat E anchors Xist RNA to the inactive $\mathrm{X}$ chromosomal compartment through CDKN1Ainteracting protein (ClZ1). Proc Natl Acad Sci. USA 114: 10654-10659.

TADA T, OBATA Y, TADA M, GOTO Y, NAKATSUJI N, TAN S, KONO T, TAKAGI $N$ (2000). Imprint switching for non-random X-chromosome inactivation during mouse oocyte growth. Development 127: 3101-3105.

TAKAGI N, SASAKI M (1975). Preferential inactivation of the paternally derived X chromosome in the extraembryonic membranes of the mouse. Nature256: 640-642.

THORNHILL AR, BURGOYNE PS (1993). A paternally imprinted X chromosome retards the development of the early mouse embryo. Development 118: 171-4.

TIAN D, SUN S, LEE JT (2010). The long noncoding RNA, Jpx, is a molecular switch for $X$ chromosome inactivation. Cell 143: 390-403.

VALLOT C, OUIMETTE J-F, MAKHLOUF M, FÉRAUD O, PONTIS J, CÔME J, MARTINAT C, BENNACEUR-GRISCELLI A, LALANDE M, ROUGEULLE C (2015). Erosion of $X$ chromosome inactivation in human pluripotent cells initiates with XACT coating and depends on a specific heterochromatin landscape. Cell Stem Cell 16: 533-546.

VALLOT C, PATRAT C, COLLIER AJ, HURET C, CASANOVA M, LIYAKAT ALI TM, TOSOLINI M, FRYDMAN N, HEARD E, RUGG-GUNN PJ, ROUGEULLE C (2017) XACT noncoding RNA competes with XIST in the control of X chromosome activity during human early development. Cell Stem Cell 20: 102-111.

VASKOVA EA, DEMENTYEVA EV, SHEVCHENKO AI, PAVLOVA SV, GRIGOR'EVA EV, ZHELEZOVA AI, VANDEBERG JL, ZAKIAN SM (2014). Dynamics of the two heterochromatin types during imprinted $X$ chromosome inactivation in vole Microtus levis. PLoS One 9: e88256.

VASKOVA EA, MEDVEDEV SP, SOROKINA AE, NEMUDRYY AA, ELISAPHENKO EA, ZAKHAROVAIS, SHEVCHENKO AI, KIZILOVAEA, ZHELEZOVAAI, EVSHIN IS, et al., (2015). Transcriptome characteristics and X-chromosome inactivation status in cultured rat pluripotent stem cells. Stem Cells Dev 24: 2912-2924.

WAKE N, TAKAGI N, SASAKI M (1976). Non-random inactivation of $X$ chromosome in the rat yolk sac. Nature 262: $580-581$.

WANG J, MAGER J, CHEN Y, SCHNEIDER E, CROSS JC, NAGY A, MAGNUSON $T$ (2001). Imprinted $X$ inactivation maintained by a mouse Polycomb group gene. Nat Genet 28: 371-375

WANG F, MCCANNELL KN, BOŠKOVIĆ A, ZHU X, SHIN J, YU J, GALLANT J, BYRON M, LAWRENCE JB, ZHU LJ, JONES SN, RANDO OJ, FAZZIO TG, BACH I (2017). Rlim-dependent and -independent pathways for $X$ chromosome inactivation in female ESCs. Cell Rep 21: 3691-3699.

WANG X, MILLER DC, CLARK AG, ANTCZAK DF (2012). Random X inactivation in the mule and horse placenta. Genome Res 22: 1855-1863.

WUTZ A, JAENISCH R (2000). A shift from reversible to irreversible $X$ inactivation is triggered during ES cell differentiation. Mol Cell 5: 695-705.

WUTZA, RASMUSSEN TP, JAENISCH R (2002). Chromosomal silencing and localization are mediated by different domains of Xist RNA. Nat Genet 30: 167-174.

XIONG Y, CHEN X, CHEN Z, WANG X, SHI S, WANG X, ZHANG J, HE X (2010). RNA sequencing shows no dosage compensation of the active $X$-chromosome. Nat Genet 42: 1043-1047.

YAMADA N, HASEGAWA Y, YUE M, HAMADA T, NAKAGAWA S, OGAWA Y (2015). Xist exon 7 contributes to the stable localization of Xist RNA on the inactive Xchromosome. PLoS Genet 11: e1005430.

YILDIRIM E, SADREYEV RI, PINTER SF, LEE JT (2011). X-chromosome hyperactivation in mammals via nonlinear relationships between chromatin states and transcription. Nat Struct Mol Biol 19: 56-61.

YIN S, DENG W, ZHENG H, ZHANG Z, HU L, KONG X (2009). Evidence that the nonsense-mediated mRNA decay pathway participates in $X$ chromosome dosage compensation in mammals. Biochem Biophys Res Commun 383: 378-382.

ZHAO J, SUN BK, ERWIN JA, SONG J-J, LEE JT (2008). Polycomb proteins targeted by a short repeat RNA to the mouse $X$ chromosome. Science 322: 750-756. 


\section{Further Related Reading, published previously in the Int. J. Dev. Biol.}

\section{Epigenetic mechanism of FMR1 inactivation in Fragile $\mathbf{X}$ syndrome}

Merav Hecht, Amalia Tabib, Tamar Kahan, Shari Orlanski, Michal Gropp, Yuval Tabach, Ofra Yanuka, Nissim Benvenisty, Ilana Keshet and Howard Cedar

Int. J. Dev. Biol. (2017) 61: 285-292

https://doi.org/10.1387/ijdb.170022hc

X-chromosome inactivation in differentiating mouse embryonic stem cells carrying X-linked GFP and lacZ transgenes Shirin Farivar, Shinpei Yamaguchi, Michihiko Sugimoto and Nobuo Takagi

Int. J. Dev. Biol. (2004) 48: 629-635

http://www.intjdevbiol.com/web/paper/041898sf

Evidence that the testis determination pathway interacts with a non-dosage compensated, $X$-linked gene P S Burgoyne, R Lovell-Badge and A Rattigan

Int. J. Dev. Biol. (2001) 45: 509-512

http://www.intjdevbiol.com/web/paper/11417892

Of microbes, mice and man

M Monk

Int. J. Dev. Biol. (2001) 45: 497-507

http://www.intjdevbiol.com/web/paper/11417891

$\mathrm{X}$ chromosome inactivation revealed by the $\mathrm{X}$-linked lacZ transgene activity in periimplantation mouse embryos

M Sugimoto, S S Tan and N Takagi

Int. J. Dev. Biol. (2000) 44: 177-182

http://www.intjdevbiol.com/web/paper/10794075

$\mathrm{X}$ chromosome inactivation revealed by the $\mathrm{X}$-linked lacZ transgene activity in periimplantation mouse embryos

M Sugimoto, S S Tan and N Takagi

Int. J. Dev. Biol. (2000) 44: 177-182

http://www.intjdevbiol.com/web/paper/10794075

X-chromosome inactivation during the development of the male urogenital ridge of the mouse

R V Jamieson, S X Zhou, S S Tan and P P Tam

Int. J. Dev. Biol. (1997) 41: 49-55

http://www.intjdevbiol.com/web/paper/9074937
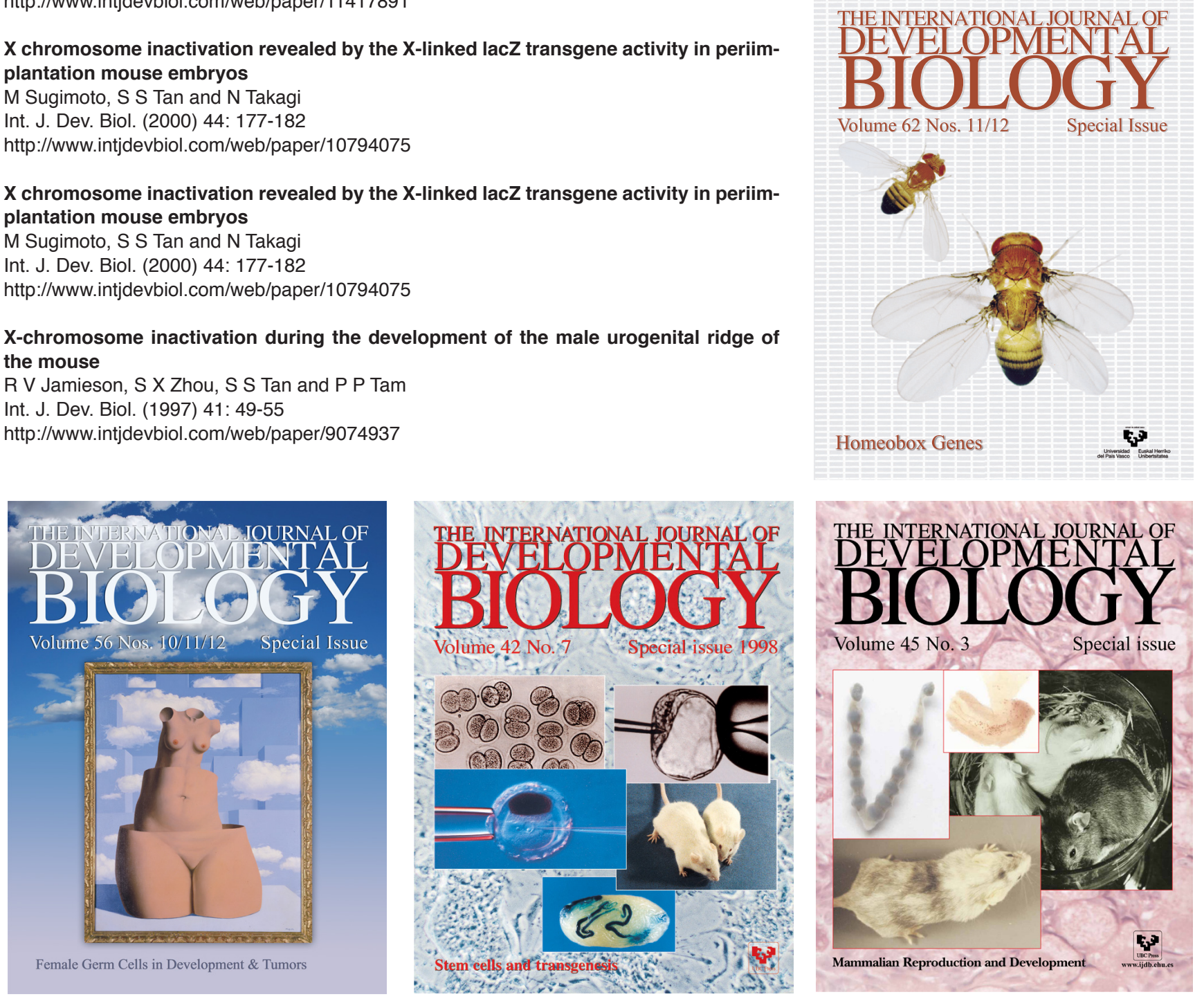